\title{
Detection of the -1082 G/A Promoter Polymorphism of Interleukin-10 Gene by ARMS-PCR Technique among some Iraqi Rheumatoid Arthritis Patients
}

\author{
Owayes M. Alhassani* $^{*}$ Adnan F. Al-Azawie $^{* *}$ Wasan N. Hussain $^{* * *}$ \\ Omama M. alhassani* Akeel H. Al-Assie ${ }^{* *}$ \\ * Department of Biology/College of Science/ University of Mosul \\ ** Department of Biology/College of Science/ University of Tikrit \\ *** Department of Biology/College of Education / University of Tikrit
}

(Received 10/11/2013;Accepted 16/12/2013)

\begin{abstract}
Rheumatoid arthritis (RA) is a chronic inflammatory disease in which interleukin (IL)-10 gene plays an important role. There are, however, controversial reports that IL-10 promoter polymorphism may be an independent marker of susceptibility and severity of RA. The aim of the present study was to examine the IL-10 promoter polymorphism among RA patients.

The aim of this study was to investigate the association between IL-10 G-1082A promoter polymorphism of interleukin-10 gene in some Iraqi rheumatoid arthritis patients using ARMS-PCR technique.

We examined 70 RA patients (60 females and 10 males; aged: $20-74$ years, mean: 51.7 years) were recruited from a private clinic in different region of Salahaddin governorate and 50 healthy individuals (40 females and 10 males; age: matching with patients) who were the staff of Tikrit University and hospital workers. The venous blood samples $(5 \mathrm{ml})$ were collected from all the participants at the time of clinical examination, aliquoted in plain and EDTA vacutainers for the determination of erythrocyte sedimentation rate, C-reactive protein, presence of RFs. Genomic DNA was isolated from the whole-blood samples of all the patients and control subjects. The IL-10 -1082 G/A polymorphism genotyping Amplification Refractory Mutation System- Polymerase Chain Reaction (ARMS-PCR) method was used.

ESR rate and RF positivity Levels of CRP were found as high as $\geq 20,86.3 \%$ among patients, while all the healthy individuals were negative for this test except for a few number.

The genotype GA for the -1082 G/A polymorphism of the IL-10 gene promoter was the most frequently observed genotype in both patients and controls, however, the distribution of the GG and AA genotype in patients and control was different. While genotype AA has a higher frequency than GG in patients $(27.04 \mathrm{vs} .23 .04)$, genotype GG was more frequently observed than AA in controls (46.08vs. 0.08).
\end{abstract}

Keywords: Interleukin-10 Promoter polymorphism, Rheumatoid arthritis, ARMS-PCR

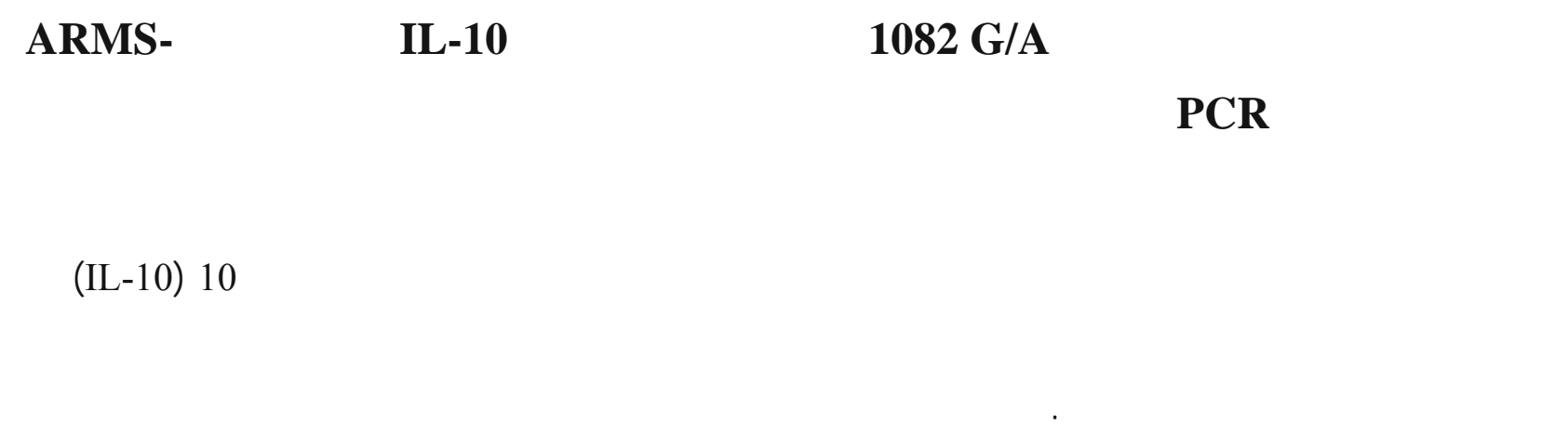


وتهوف هذه الدرلسة اله لمكانية تحديد العلاقة بين التباين الوراثي في الموقع (1082 G\A) للبروموتر التاع للجين IL-10 ومرض التهاب المفاصل الرثوي في العراق بالاعتماد على تقنية ARMS-PCR.

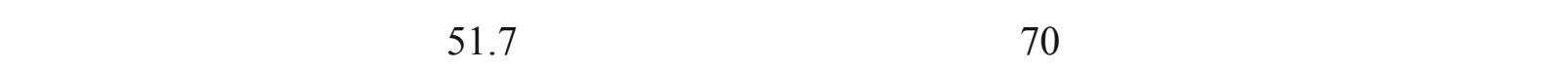
صلاح الين، و 50شخصا إناثا ونكورا بوصفهم مجموعةسيطرة لها معدل الفئة العمرية ذاتتها، لتحديد التباين الوراثي في الموقع 1082 G\A للبروموتر التاع للجين

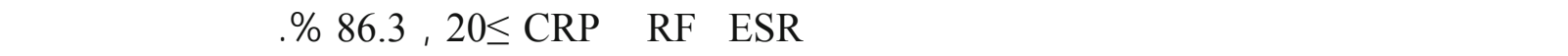
بلن النط الوراثي لتبن GA في الموقع 1082 التانع للبروموتر الخاص بالجين IL-10 gene كثر تكرارا من بقية الانمط الوراثية لدى المرضف ومجموعة للسطرة وان تولجد الانمط الوراثية AA,GG كلن مختلفاَ لدى المرض ومجموعة للسيطرة اذ تبين بلن النط الوراثي AA كلن تكراره لدى المرض اعلى من الأصحاء (27.04vs.23.04) في حين النط الوراثي

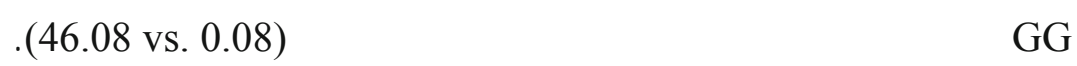

\section{INTRODUCTION}

Rheumatoid arthritis (RA) is an inflammatory disease of unknown etiology with a considerable variability. Both genetic and environmental factors can contribute to the susceptibility of disease initiation as well as the severity of disease course (Albani et al., 1992 ; Hee et al ., 2007). The major histo compatibility complex (MHC) class-II region is an important susceptibility factor, and HLA-DR4 alleles are also associated with a more severe disease course (Kishimoto et al., 1995). However, the contribution of the HLA-DR4 alleles represents no more than $30-50 \%$ of the genetic background of RA (De Waal Malefyt et al., 1991; Fiorentino et al., 1991).

Cytokines with polymorphic gene sequences are potential markers of disease severity as their gene products are involved in the pathogenesis of RA. Differences in severity between individuals could be related to different levels of cytokine production due to functional differences resulting from polymorphisms in their genes (Omar et al., 2008).

Interleukin-10 (IL-10) is a major immune regulatory cytokine, usually considered to mediate the down regulation of the inflammatory response in RA (Petr et al ., 2009 ; Binwu et al ., 2011). Various lines of research suggest an important role of IL-10 in the pathogenesis of joint destruction in RA. Some effects of IL-10 gene, however, are not anti-inflammatory; for example, the activation of B lymphocytes proliferation and differentiation (Candore et al., 2002).

There is an evidence to show that the production of human IL-10 is controlled at the transcription level, most likely through some of the regulatory sequences present in the promoter region of the IL-10 gene. A number of proximal single nucleotide polymorphisms (SNPs) has been identified in the promoter region of the human IL-10 gene, e.g., $-1087 \mathrm{G}>\mathrm{A}$ (vs1800896), $-824 \mathrm{C}>$ $\mathrm{T}(\mathrm{vs} 1800871)$, and $-597 \mathrm{C}>\mathrm{A}(\mathrm{vs} 1800872)$. The SNPs at sites $-1082 \mathrm{G}>\mathrm{A},-824 \mathrm{C}>\mathrm{T}$, and $-597 \mathrm{C}>\mathrm{A}$ are located at the putative regulatory regions in the promoter of the human IL-10 gene (Spaska et al ., 2006 ; Omar et al., 2008).

The IL-10 gene maps to the junction of 1q31-q32 ( Hutchinson et al., 1999 ; Young et al., 2012). The IL-10 gene is highly polymorphic with a number of single nucleotide polymorphisms in the promoter region and two microsatellite loci, IL10.R and IL10.G, 4 and $1.1 \mathrm{~kb} 5^{\prime}$ of the transcription initiation site, respectively (Westendorp et al., 1997 ; Pawlik et al., 2005). The association of RA with promoter region polymorphisms in IL-10 has been studied in different ethnic populations with inconsistent results. Moreover, there was no data on the frequency of these polymorphisms in Iraqi RA patients. The aim of this study was to investigate the association between IL-10 G-1082A promoter polymorphism of interleukin-10 gene among some Iraqi rheumatoid arthritis patients using ARMS-PCR technique. 


\section{Subjects}

\section{MATERIALS AND METHODS}

The studied samples consisted of 70 RA patients (60 females and 10 males; aged: $20-74$ years, mean: 51.7 years) were recruited from a private clinic in different regions of Salahaddin governorate during the period from (December 2012 - February 2013) and 50 healthy individuals (40 females and 10 males; age: matching with patients) who were staff of Tikrit University and hospital workers. The diagnosis of RA was made in accordance with the criteria of the American College of Rheumatology (ACR) modified in 1987, information regarding the demographic features such as age, marital history, parity, gestational age, family history, consanguinity, etc was obtained from all these subjects with the help of a standard perform questionnaire.

\section{Sample Collection}

The venous blood samples $(5 \mathrm{ml})$ were collected from all the participants at the time of clinical examination, aliquoted in plain and EDTA vacationers for the determination of erythrocyte sedimentation rate, C-reactive protein and presence of RFs. The remainder of blood samples was stored at $-20^{\circ} \mathrm{C}$ for further molecular analysis.

\section{DNA Extraction}

Genomic DNA was isolated from the blood samples of all the patients and control subjects using a method described by (Al-azawy,2012). DNA concentration and purity were determined by measuring the absorbance of diluted DNA solution at 260 and $280 \mathrm{~nm}$ using (Nano drop Thermo scientific, Germany) and detected the optimum DNA concentration for ARMS-PCR analysis. The quality of the DNA was determined using agarose gel electrophoresis stained with ethidium bromide, samples were stored at $-20{ }^{\circ} \mathrm{C}$ until further use.

\section{Determination of IL-10-1082G/A polymorphism by ARMS-PCR:}

For IL-10 -1082 G/A polymorphism genotyping Amplification Refractory Mutation SystemPolymerase Chain Reaction (ARMS-PCR) method was used as described by Bhayal et al., (2012). For each polymorphism two separate reactions were performed. Each reaction contained one of the two-allele specific forward primers and a generic anti sense primer. The primers used are as follows: a common (CF) anti-sense primer 5'-GTA AGC TTC TGT GGC TGG AGT C-3'; (FG) Sense 5'- AAC ACT ACT AAG GCT TCT TTG GGT G-3'G-primer; (FA) Sense 5'-AAC ACT ACT AAG GCT TCT TTG GGT A-3'.These reactions amplify allele specific sequence of $161 \mathrm{bp}$ of the promoter of IL-10 gene.The PCR amplification was performed in a total volume of $25 \mu 1$. $12.5 \mu \mathrm{L}$ of Go Taq green master mix $2 \mathrm{X}$ (green master mix is a premixed ready to use solution containing Taq DNA polymerase, dNTPs, $\mathrm{MgCl} 2$ and reaction buffers) supplied by promega company (USA), $2 \mu \mathrm{L}(100 \mathrm{ng})$ of genomic DNA, $1 \mu \mathrm{l}$ of each primer $(10 \mathrm{pmol} / 1 \mu \mathrm{L})$ and made up to $25 \mu \mathrm{L}$ with nucleases free water. The thermal cycling was as follows: Initial denaturation at $95{ }^{\circ} \mathrm{C}$ for $5 \mathrm{~min}$, followed by 35 cycles of $95^{\circ} \mathrm{C}$ for $30 \mathrm{~s}, 63^{\circ} \mathrm{C}$ for $30 \mathrm{~s}$, and $72{ }^{\circ} \mathrm{C}$ for $30 \mathrm{~s}$, one cycle. The final extensionat $72{ }^{\circ} \mathrm{C}$ for $5 \mathrm{~min}$. The amplified PCR products (161bp) were separated by $1.5 \%$ agarose gel electrophoresis in the presence of $1 \mathrm{~Kb}$ DNA ladder (Biolabs-England) as a molecular size marker, and visualized using a gel documentation System after ethidiumbromide staining (10 mg\ml).

\section{Statistical analysis}

The allelic and genotype frequencies of the IL-10 gene in thecontrol and case groups were calculated bydirect count. Chi-square $\left(\chi^{2}\right)$ test was used to compare allele/genotype frequencies between groups, and Hard-Weinberg equilibrium of genotype distribution.

\section{RESULTS AND DISCUSSION}

Age and gender distribution of patients and control is listed in table-1. The higher frequencies of disease were observed at third $(24 \%)$ and fourth decade $(84 \%)$ respectively. A higher incidence was noticed among the females $(74.0 \%)$ rather than the males; in 2.8:1 ratio. 
Table 1: Distribution of Rheumatoid Arthritis patients by age and gender in comparison with healthy samples

\begin{tabular}{|c|c|c|c|c|}
\hline \multirow{2}{*}{$\begin{array}{c}\text { Age Groups } \\
\text { (Year) }\end{array}$} & \multicolumn{4}{|c|}{ Studying sample } \\
\cline { 2 - 5 } & No. & $\mathbf{\%}$ & \multicolumn{2}{c|}{ Healthy sample } \\
\hline$<20$ & 8 & 8 & 8 & $\mathbf{0}$ \\
\hline $20-29$ & 9 & 9 & 9 & 16 \\
\hline $30-39$ & 24 & 24 & 19 & 38 \\
\hline $40-49$ & 17 & 17 & 8 & 16 \\
\hline $50-59$ & 20 & 20 & 4 & 8 \\
\hline $60-69$ & 16 & 16 & 2 & 4 \\
\hline $70-79$ & 6 & 6 & - & - \\
\hline Female & 84 & 84 & 34 & 71 \\
\hline Male & 16 & 16 & 16 & 29 \\
\hline Total & 100 & 100 & 50 & 100 \\
\hline
\end{tabular}

* Higher frequency

The demographic features of the RA Iraqi patients in addition to the healthy normal individuals are listed in Table (2).

Table 2: Clinical and demographic parameters of RA patients and healthy samples

\begin{tabular}{|c|c|c|}
\hline Disease in years & RA Patients & Healthy sample \\
\hline Age of subjects & $20-60$ Year & $20-60$ Year \\
\hline 1 - 15 Year & & - \\
\hline Age of RA onset years & 18 & - \\
\hline ESR & $\geq 20$ & $\leq 10$ \\
\hline RF test positivity \% & 78 & 7 \\
\hline CRP test positivity \% & 90 & 5 \\
\hline
\end{tabular}

The average of the patient's age was between 18-79 years where as the average of the age of the healthy control group was between 17-67 years. ESR rate and RF positivity Levels of CRP were found as high as $\geq 20,86.3 \%$ among patients, while all the healthy individuals were negative for this test except for a few number.

Based on the above definition of the genotype for the $-1082 \mathrm{G} / \mathrm{A}$ polymorphism of the IL-10 gene promoter, the genotype distributions and allele frequencies of the SNP were counted, calculated and summarized in Table (3). The genotype frequencies of the $-1082 \mathrm{G} / \mathrm{A}$ SNP in RA patient and normal control groups were all in accordance with the Hardy-Weinberg equilibrium (data not shown, $\mathrm{P}$ value 0.01 ).

Table 3: Distribution of RA patients and healthy samples according to Allele frequency and genotyping

\begin{tabular}{|c|c|c|c|c|c|c|c|c|}
\hline Group & No. & Allele & $\begin{array}{c}\text { Allele } \\
\text { Frequency }\end{array}$ & Genotype & $\begin{array}{l}\text { Expected } \\
\text { No. }\end{array}$ & $\begin{array}{c}\text { Observed } \\
\text { No. }\end{array}$ & $\chi^{2}$ & P value \\
\hline \multirow{3}{*}{$\begin{array}{c}\text { RA } \\
\text { Patients }\end{array}$} & \multirow{3}{*}{100} & $\mathrm{G}$ & 0.48 & GG & 11 & 23.04 & \multirow[t]{3}{*}{23.27} & \multirow[t]{3}{*}{0.01} \\
\hline & & \multirow[t]{2}{*}{$\bar{A}$} & \multirow[t]{2}{*}{0.52} & GA & 74 & 49.92 & & \\
\hline & & & & $\mathrm{AA}$ & 15 & 27.04 & & \\
\hline \multirow{3}{*}{$\begin{array}{l}\text { Healthy } \\
\text { Samples }\end{array}$} & \multirow{3}{*}{50} & $\mathrm{G}$ & 0.96 & $\overline{\mathrm{GG}}$ & 46 & 46.08 & \multirow{3}{*}{0.087} & \multirow{3}{*}{0.01} \\
\hline & & $\mathrm{A}$ & 0.04 & $\overline{G A}$ & 4 & 3.84 & & \\
\hline & & & & $\overline{\mathrm{AA}}$ & 0 & 0.08 & & \\
\hline
\end{tabular}

The genotype GA forth -1082 G/A polymorphism of the IL-10 gene promoter was the most frequently observed genotype in both patients and controls ( 74 and 46 respectively). However, the 
distribution of the GG and AA genotype in patients and control was different. While genotype AA has a higher frequency than GG in patients (27.04vs.23.04), genotype GG was more frequently observed than AA in controls (46.08vs. 0.08). Further calculation of allelic frequency indicated a higher frequency of $A$ than that of $G$ in patients $(0.52 \mathrm{vs}$. 0.48$)$. In contrast, a lower frequency of $A$ allele than $G$ allele in the control group (0.04vs. 0.96). Chi-square analysis was performed to compare the $-1082 \mathrm{G} / \mathrm{A}$ polymorphism of the IL-10 gene promoter genotype distribution and allele frequency in patient and control groups, and it was found that both genotype and allele distribution were significantly difference in the two groups. The calculated chi-square of the patient's group was to be 23.27 more than $\chi 2$ tabulated (6.63), so there are significantly different between genotypes of RA patients $(\mathrm{P}=0.01)$. In case of controls, no significant association was found for controls $(\mathrm{P}=0.01)$ and calculated chi-square was found to be 0.08 less than $\chi 2$ tabulated (6.63). The results suggest that allele $\mathrm{A}$ is significantly associated with RA.

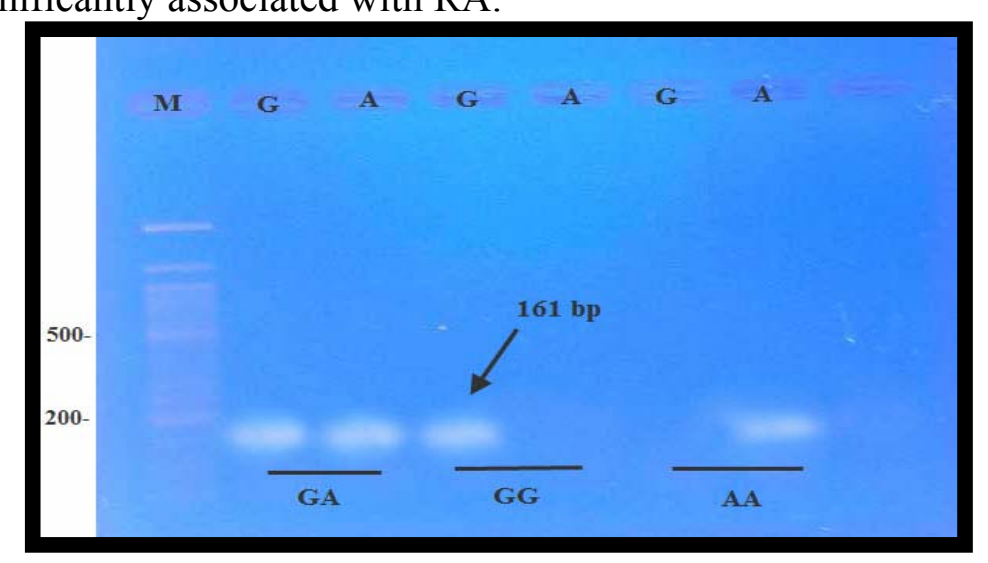

Fig. 1: A representative agarose (1.5\%) gel electrophoresis of ARMS-PCR products for IL-101082 G/A polymorphisms. M: 100bp size DNA ladder.

Several studies examined the role of the association of IL-10 promoter polymorphisms for RA susceptibility and severity (Andrzej et al ., 2005 ; Fei et al., 2012). Padyukov et al., (2004) showed that -1082 AA genotype frequency in women with RA was significantly lower than controls. Pawlik et al., (2005) found that -1082 GG allele and GCC/GCC haplotypes frequency were significantly higher than controls. Hajeer et al., (1998) found no significant difference in allele frequencies of IL-10 polymorphisms between RA patients and controls, but they showed that the genotypes encoding low IL-10 gene expression correlated with IgA rheumatoid factor seropositive RA (Hajeer et al., 1998). Three further studies also failed to show any association between IL-10 polymorphism and RA (Omar et al., 2008).

\section{REFERENCES}

Al-azawy, A.F. (2012). A rapid and non-enzymatic method for genomic DNA extraction from whole blood and some other mammalian tissues. J. Tikrit Univ. for Agri. Sci., 12(4).

Albani, S.; Carson, DA.; Roudier, J. (1992). Genetic and environmental factors in the immune pathogenesis of rheumatoid arthritis. Rheum Dis. Clin. North. Am., 18,729-740

Andrzej, P.; Mateusz, K.; Barbara, G.; Magdalena, H.; Marek, D. (2005). Interleukin-10 promoter polymorphism in patients with rheumatoid arthritis. Clin. Rheumatol. 24, 480-484.

Bhayal, A.C. (2012). Association of interleukin-10 Promoter Polymorphism (-1082 G/A) and Gastric Cancer in Andhra Pradesh Population of South India. Iran J. Cancer Rev. 5(3), $117-$ 123.

Binwu, Y.; Yunying, S.; Xiaofu, P.; Xingbo, S.; Zhunchun, H.; Qian, N.; Lanlan, W. (2011). Association of polymorphisms in the human IL-10 and IL-18 genes with rheumatoid arthritis. Mol Biol Rep., 38,379-385. 
Candore, G.; Lio D.; Colonna, R.; Caruso, C. (2002). Pathogenesis of autoimmune diseases associated with 8.1 ancestral haplotype: effect of multiple gene interactions. Autoimmunity Rev., 1, 29-35.

De Waal Malefyt, R.; Abrams, J.; Bennett, B.; Figdor, C.G.; de Vries, J.E. (1991). Interleukin 10 (IL-10) inhibits cytokine synthesis by human monocytes: an autoregulatory role of IL-10 produced by monocytes. J. Exp. Med., 174, 1209-1220.

Fei, L.; Bo, L.; Wen-Tao, W.; Yong-Gang, W.; Lv-Nan, Y.; Tian-Fu, W.; Ming-Qing, X. (2012). Interleukin-10-1082G/A polymorphism and acute liver graft rejection: A meta-analysis. World J. Gastroenterol., 18(8), 847-854.

Fiorentino, D.F.; Zlotnik, A.; Mosmann, T.R.; Howard, M.; O'Garra, A. (1991). IL-10 inhibits cytokine production by activated macrophages. J. Immunol. 146, 3445-3451

Hajeer, AH.; Lazarus, M.; Turner, D.; Mageed, RA.; Vencovsky, J.; Sinnott, P. (1998). IL-10 gene promoter polymorphisms in rheumatoid arthritis. Scand J. Rheumatol. 27, 142-145

Hee, C.; Gun. S.; Rakesh. N.; Sushela. D.; Kutty. R. (2007). Comparison of single nucleotide polymorphisms in the human interleukin-10 gene promoter between rheumatoid arthritis patients and normal subjects in Malaysia. Mod Rheumatol. 17, 429-435.

Hutchinson, IV.; Pravica, V.; Hajeer, A.; Sinnott, P.J. (1999). Identification of high and low responders to allografts. Rev. Immunogenet. 1, $323-333$

Kishimoto, T.; Akira, S.; Narazaki, M.; Taga, T. (1995). Interleukin-6family of cytokines and gp130. Blood., 86,1243-1254.

Omar, A.; Gulen, H.; Vedat, H. (2008). Tumor necrosis factor-alpha and Interleukin-10 gene promoter polymorphisms in Turkish rheumatoid arthritis patients. Clin. Rheumatol. 27, 12431248.

Padyukov, L.; Hytonen, A.; Smolnikova, M.; Hahn-Zoric, M.; Nilsson, N.; Hanson, L. (2004). Polymorphism in promoter region of IL10 gene is associated with rheumatoid arthritis in women. J. Rheumatol. 31, 422-425.

Pawlik, A.; Kurzawski, M.; Szklarz, B.; Herczynska, M.; Drozdzik, M. (2005). Interleukin-10 promoter polymorphism in patients with rheumatoid arthritis. Clin. Rheumatol. 24, 480-484.

Petr, N.; Monika, P.; Jindra, G.; Zdenek, F.; Anna, V.; Miroslav, S. (2009). Association of the $-1082 \mathrm{G} / \mathrm{A}$ promoter polymorphism of interleukin-10 gene with the autoantibodies production in patients with rheumatoid arthritis. Clin. Rheumatol. 28, 899-905.

Spaska, A.; Stanilova, L.; Miteva, Z.; Karakolev, C.; Stefano V. (2006). Interleukin-10-1082 promoter polymorphism in association with cytokine production and sepsis susceptibility. Intensive Care Med. 32, 260-266.

Westendorp, R.; Langermans, J.; Huizinga W.; Elouali, A.; Verveij, C.; Boomsma, D. (1997). Genetic influence on cytokine production and fatal meningococcal disease. Lancet. 349, 170173.

Young, H.; Sang-Cheol, B.; Sung, J.; Jong, D.; Gwan, G. (2012). Associations between interleukin10 polymorphisms and susceptibility to rheumatoid arthritis: a meta-analysis. Mol. Biol. Rep. 39, 81-87. 